FACTA UNIVERSITATIS

Series: Physical Education and Sport, Vol. 16, No 2, 2018, pp. 329 - 336

https://doi.org/10.22190/FUPES180825029M

Research article

\title{
EVALUATION OF GOAL SCORING PATTERNS AND THE RELATION BETWEEN TIME AND GOAL SCORING OF FOUR UEFA CHAMPIONS LEAGUE TOURNAMENTS
}

\author{
UDC 796.332:629.397.43
}

\author{
Yiannis Michailidis' ${ }^{1}$, Athanasios Mandroukas' \\ Lazaros Vardakis ${ }^{1}$, Thomas Metaxas ${ }^{1}$ \\ ${ }^{1}$ Department of Physical Education and Sports Sciences, \\ Aristotle University of Thessaloniki, Thessaloniki, Greece \\ ${ }^{2}$ Faculty of Physical Education and Sport, Charles University, Prague, Czech Republic
}

\begin{abstract}
The purpose of this study was to compare time period and patterns of goal scoring in four UEFA Champions League (UCL) tournaments (2013-2017). All matches $(n=500)$ of the four Champions League tournaments were recorded using video and analyzed with the software Sportsscout. Chi-square methods were used for the data analysis and the level of significance was set at $p<0.05$. The time period and scoring pattern comparison between UCL tournaments did not present any significant difference $\left(X^{2}=84.500, p>0.05\right.$ for the time period, $X^{2}=25.350, p>0.05$ for open play and $X^{2}=7.503$, $p>0.05$ for set play). The 15-min analysis for each tournament did not show any significant difference if we exclude all extra time periods. However, in UCL 2013-2014 and 2015-2016 more goals were scored in the second half $\left(X^{2}=9.696, p<0.05\right.$ and $X^{2}=7.496, p<0.05$, respectively). With open play more goals were scored than set play ( $75 \%$ and $25 \%$ average, respectively). The action that scored the most goals in open play was combination and crosses $(21.6 \%$ and $22.4 \%$ respectively) and in set play was corners and penalties $(33.9 \%$, all). The results showed that no differences occurred between CLs regarding the scoring patterns and time periods of scoring. However, goal scoring might be time dependent because more goals were scored in the second half. An explanation for this could be the fatigue and the tactical strategy. About the patterns, coaches must focus on training crosses and passing combinations. Also, they should give a lot of attention to corners of set plays.
\end{abstract}

Key words: soccer, champions league, goal, video-analysis

Received August 25, 2018 / Accepted October 19, 2018

Corresponding author: Yiannis Michailidis

Aristotle University of Thessaloniki, Thessaloniki 541 24, Greece

Phone: +30 2310996000 •E-mail: ioannimd@ phed.auth.gr 


\section{INTRODUCTION}

Feedback is very useful for the learning process and plays an important role in the performance improvement of soccer players and soccer teams. One critical coaching ability is the ability to observe and recall all the crucial incidents of a match (Leite, 2013; Borrie, Jonsson, \& Magnusson, 2002). However, in a soccer match, a lot of actions take place in a moment and it is difficult for a coach to remember all this information (Franks \& Miller, 1986). Today, with help of technology, coaches and their assistants have detailed information for players' performances almost in real time (Liebermann et al., 2002; Hohmann \& Rommel, 1994).

Monitoring systems provide an incredibly big number of performance indicators for players and for teams. One of the most studied variables are the goals because they are crucial for the success of the team (Cachay \& Thiel, 2000). A lot of studies examined whether goal scoring is affected by time, and the results are controversial. Some studies mentioned that goal scoring is time dependent (Abt, Dickson, \& Mummery, 2002; Armatas \& Yiannakos, 2007; Jinshan, 1986; Reilly, 1996; Yiannakos \& Armatas, 2006) and others that it is not (Michailidis, Michailidis, Papaiakovou, \& Papaiakovou, 2004; Michailidis 2014).

One significant factor for analysis is the effort prior to a goal (Garganta, Maia \& Basto, 1997). Many studies have examined the characteristics of goals that have been scored in different tournaments (Jinshan, Xiakone, Yamanaka, \& Matsumoto, 1993; Michailidis et al., 2004; Michailidis, Michailidis, \& Primpa, 2013; Olsen, 1988). The evaluation of these characteristics can give coaches' information about the evolution of soccer.

The purpose of this study was to record and evaluate goal scoring patterns in four UCL tournaments. Another aim was to record the time that the goals were scored and to compare all the above characteristics between the four UCL tournaments.

UEFA Champions League (UCL) is one of the most interesting soccer tournaments. Thirtytwo clubs participate at the group stage, which split into 8 groups of four teams. The first two teams of each group, after the matches between them, participate in the first knockout round (16 teams) with two matches, at home and away. The winners of each pair play to the next round until the final. The final is a single match. A UCL tournament consists of 125 matches, 96 in the group phase and 29 matches in the next knock out phases.

This study compares four UCL tournaments, more specifically, from 2013 to 2017. The study compared the goals scored in relation to the time point and the action that preceded the goals in open and set play.

\section{METHODS}

\section{Procedures}

The sample consisted of 500 matches played in the group and knockout phase of UEFA UCL in the seasons of 2013-14, 2014-15, 2015-16, 2016-17. All the soccer matches video analyzed with the sport software Sportscout. The study was based on the researcher's personal observations, according to Lame $(1991,1994)$ and Singer and Willimczik (2002). Every match was analyzed by two experienced observers who were specially trained for accurate and reliable data recording. 


\section{Statistical analysis}

All data were analyzed using the statistical package for PC SPSS 16.0. A Chi-square analysis was used to determine the statistically significant differences and the level of significance was set at $\mathrm{p}<0.05$. Also, we used descriptive statistics, consisting of a frequency distribution.

\section{RESULTS}

No statistical differences were found between the tournaments for the average number of goals $\left(\mathrm{X}^{2}=80.135, \mathrm{p}>0.05\right)$ (Figure $\left.1 \mathrm{~A}\right)$.

Statistical analysis for the comparison of UCLs about the time that the goals were scored and the way that the goals were scored (open and set play) in the group and knock out phase did not show any significant difference $\left(15\right.$-min periods: $X^{2}=84.500, p>0.05$, open play: $X^{2}=25.350, p>0.05$, set play: $X^{2}=7.503, p>0.05$, open play group: $X^{2}=26.455$, $p>0.05$, set play group: $X^{2}=8.569, p>0.05$, open play knock out: $X^{2}=29.136, p>0.05$, set play knock out: $\left.\mathrm{X}^{2}=5.989, \mathrm{p}>0.05\right)$.

Statistical analysis of the goals scored in each UCL showed significant differences in all factor subcategories, except the factor set play in the knock out phase. The results of the statistical analysis are presented in Table 1.

Table 1 Statistical results from time periods and actions before goals.

\begin{tabular}{lcccc}
\hline Variables & & \multicolumn{2}{c}{ Year } & \\
& $2013-2014$ & $2014-2015$ & $2015-2016$ & $2016-2017$ \\
\hline 15-min periods & $\mathrm{X}^{2}=31.213$ & $\mathrm{X}^{2}=193.931$ & $\mathrm{X}^{2}=129.818$ & $\mathrm{X}^{2}=190.205$ \\
& $\mathrm{p}<0.01$ & $\mathrm{p}<0.01$ & $\mathrm{p}<0.01$ & $\mathrm{p}<0.01$ \\
15-min periods & $\mathrm{X}^{2}=7.586$ & $\mathrm{X}^{2}=9.124$ & $\mathrm{X}^{2}=11.036$ & $\mathrm{X}^{2}=8.407$ \\
without extra time & $\mathrm{p}=0.181$ & $\mathrm{p}=0.104$ & $\mathrm{p}=0.051$ & $\mathrm{p}=0.135$ \\
Open play & $\mathrm{X}^{2}=85.543$ & $\mathrm{X}^{2}=115.992$ & $\mathrm{X}^{2}=94.787$ & $\mathrm{X}^{2}=98.112$ \\
& $\mathrm{p}<0.01$ & $\mathrm{p}<0.01$ & $\mathrm{p}<0.01$ & $\mathrm{p}<0.01$ \\
Set play & $\mathrm{X}^{2}=33.341$ & $\mathrm{X}^{2}=35.975$ & $\mathrm{X}^{2}=33.340$ & $\mathrm{X}^{2}=46.745$ \\
& $\mathrm{p}=0.01$ & $\mathrm{p}<0.01$ & $\mathrm{p}<0.01$ & $\mathrm{p}<0.01$ \\
Open play group & $\mathrm{X}^{2}=75.406$ & $\mathrm{X}^{2}=104.620$ & $\mathrm{X}^{2}=83.360$ & $\mathrm{X}^{2}=79.444$ \\
phase & $\mathrm{p}<0.01$ & $\mathrm{p}<0.01$ & $\mathrm{p}<0.01$ & $\mathrm{p}<0.01$ \\
Open play knockout & $\mathrm{X}^{2}=20.130$ & $\mathrm{X}^{2}=23.245$ & $\mathrm{X}^{2}=17.562$ & $\mathrm{X}^{2}=17.127$ \\
phase & $\mathrm{p}=0.01$ & $\mathrm{p}<0.01$ & $\mathrm{p}=0.025$ & $\mathrm{p}=0.017$ \\
Set play group phase & $\mathrm{X}^{2}=22.485$ & $\mathrm{X}^{2}=33.522$ & $\mathrm{X}^{2}=24.395$ & $\mathrm{X}^{2}=33.000$ \\
& $\mathrm{p}<0.01$ & $\mathrm{p}<0.01$ & $\mathrm{p}<0.01$ & $\mathrm{p}<0.01$ \\
Set play knockout & $\mathrm{X}^{2}=5.560$ & $\mathrm{X}^{2}=1.429$ & $\mathrm{X}^{2}=6.000$ & $\mathrm{X}^{2}=7.455$ \\
phase & $\mathrm{p}=0.135$ & $\mathrm{p}=0.699$ & $\mathrm{p}=0.12$ & $\mathrm{p}=0.059$ \\
Open play-Set pay & $\mathrm{X}^{2}=103.168$ & $\mathrm{X}^{2}=98.631$ & $\mathrm{X}^{2}=82.906$ & $\mathrm{X}^{2}=83.635$ \\
& $\mathrm{p}<0.01$ & $\mathrm{p}<0.01$ & $\mathrm{p}<0.01$ & $\mathrm{p}<0.01$ \\
\hline & \multicolumn{2}{c}{$*$ Statistical differences $(\mathrm{p}<0.05)$} & &
\end{tabular}

There are statistical differences between all extra time periods with other 15-minute time periods. However, if we exclude the extra time periods, there are no significant differences between the other time periods (Figure 1B). The statistical analysis showed a 
significant difference in UCL 2013-2014 and 2015-2016 in the goals scored in the second half compared to the ones scored in the first half $\left(X^{2}=9696, p<0.05\right.$ and $X^{2}=7.496$, $\mathrm{p}<0.05$, respectively) (Figure 1C).
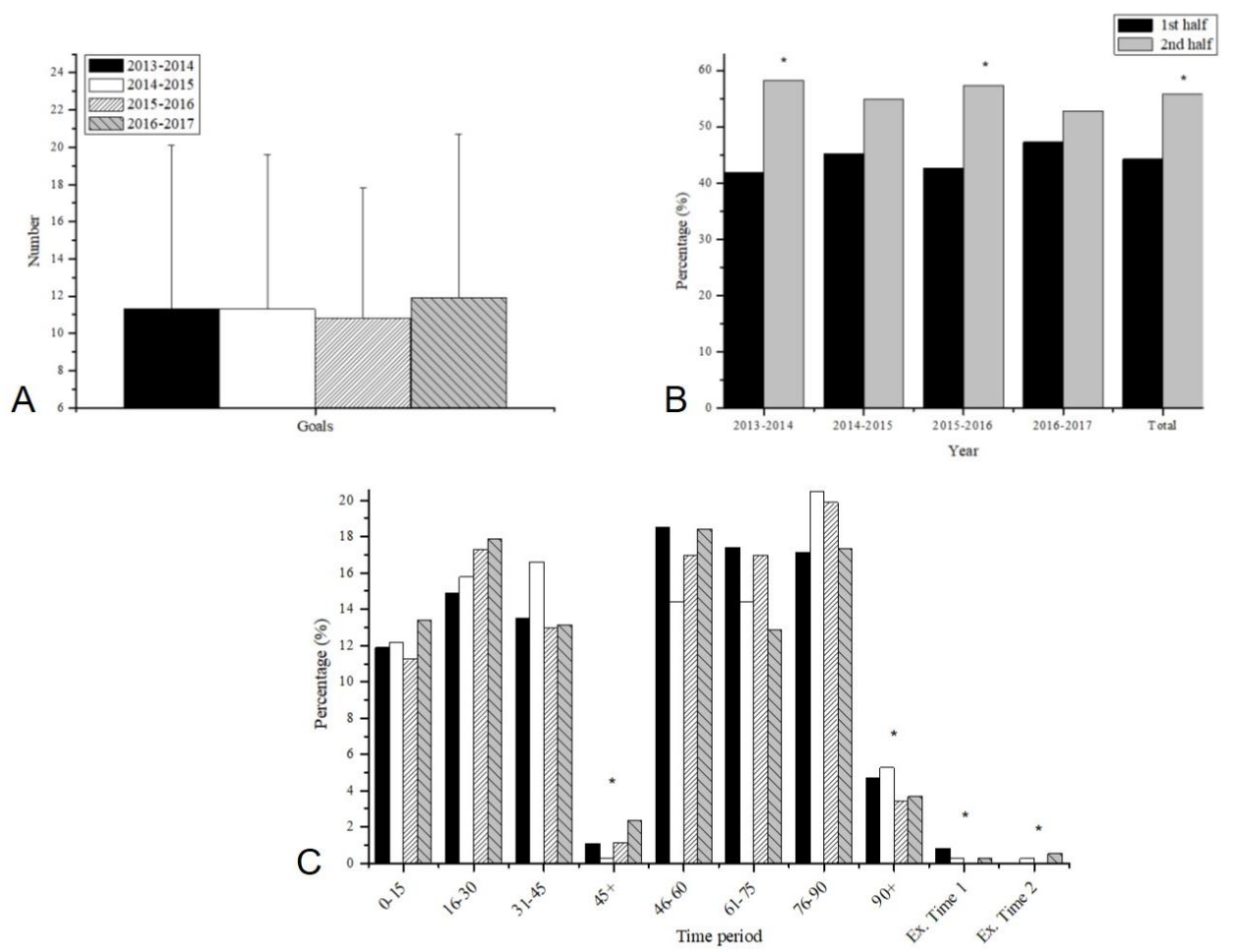

Fig. 1 A. Mean number of goals that scored in each UCL tournament.

B. Percentage of goals in each half of the mach,

* denotes statistical differences with the first half $(\mathrm{p}<0.05)$.

C. Percentage of goals that scored in each time period,

* denotes statistical differences with the other time periods $(\mathrm{p}<0.05)$.

In these four UCLs, the most goals scored after combinations or crosses and these two subcategories showed the most significant differences with the other subcategories of open play (cutbacks, diagonals, running with the ball, long range shots, forward passes, defensive errors, own goals) (Figure 2A). A statistical analysis between the subcategories of set plays (corners, free kicks-direct, free kicks-indirect, penalties, throw-ins) showed significant differences in all UCLs. In the category of set plays, the most goals were scored after corners and penalties in comparison with the other subcategories (Figure 2B). 

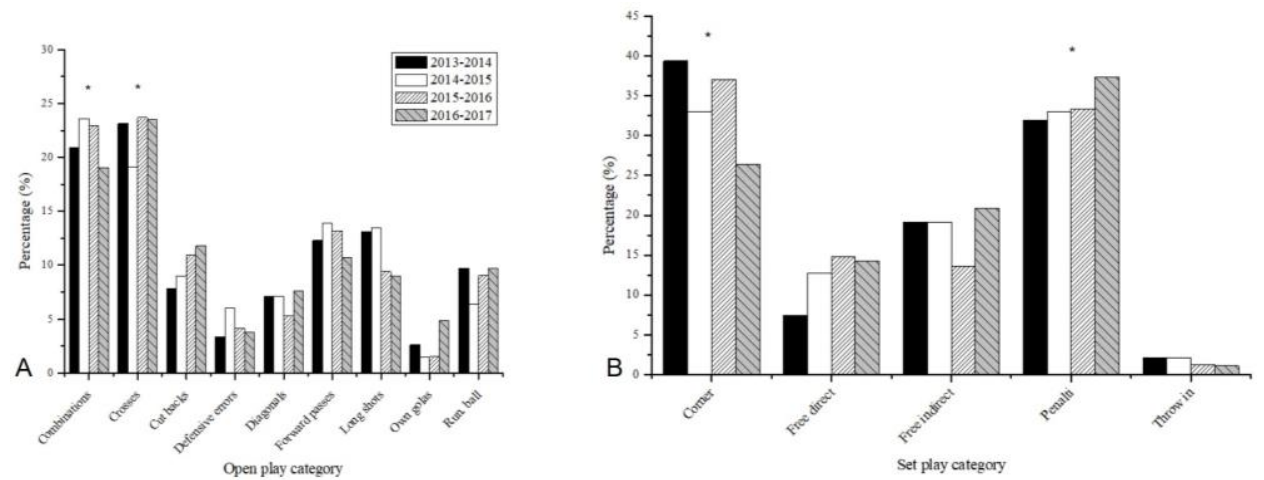

Fig. 2 A. The action that performed before the goal in open play.

B. The kind of set play that performed before the goal.

* Denotes statistical difference with the other subcategories

\section{DISCUSSION}

The purpose of this study was to record the time when goals were scored. The results of the present study indicate differences between the time periods. However, when excluding extra time periods there are no differences. Additionally, there was no significant difference in the time periods between the four UCL tournaments. In all UCL tournaments, more goals were scored in the second half, and in two of the tournaments significant differences were observed. Relevant studies mentioned that more goals were scored in the second half (Armatas \& Yiannakos, 2007; Armatas, Yiannakos, \& Sileloglou, 2007; Yiannakos \& Armatas, 2006).

Relations between time periods and the number of goals that were scored in a tournament were mentioned in numerous studies (Abt et al., 2002; Michailidis, 2014; Drust, Reilly, \& Rienzi, 1998; Reilly, 1996; Ridder, Cramer, \& Hopstaken, 1994; Yiannakos \& Armatas, 2006). However, some researchers did not observe any correlation (Jinshan, 1986; Michailidis et al., 2004; Michailidis et al., 2013). Maybe one reason for the fact that more goals were scored in the second half is the fatigue of the players. A lot of studies mention that in the second half, players cover less distance (Drust et al., 1998; Krustrup et al., 2006; Mohr et al., 2004b; Van Gool, Van Gerven, \& Boutmans (1988). Also, they rely less on high intensity energy (Mohr et al., 2005; Mohr, Krustrup, Nybo, Nielsen, \& Bangsbo, 2004a). All the above indicates that fatigue leads players to make more mistakes, and some of them could lead to scoring more goals (Armatas et al., 2007). Tactical strategy plays a significant role in scoring. A lot of times, teams at the end of a play chase a result and the coaches with their players take greater risks during this time in order to effect an outcome (Abt et al., 2002). Additionally, Abt et al. (2002) mentioned that scoring in the last minutes of each half is a result of lapses in concentration.

Statistical analysis about the way that goals scored in open play showed that in the above four UCL tournaments the most goals were scored after a combination or after a cross. A similar variation was presented in the group and knock out phase. In relative studies with national teams it was observed that long range shots are the first or second 
most frequent way of scoring the most goals (Lottermann, 2000; Michailidis, 2014; Wedegartner, 2004). Most teams try to ensure their goal post with a lot of players in front of their penalty box, so it is difficult for the opponent to split up this defense strategy. When the players must face this kind of defense, coaches urge them to play with combinations or from the wings. The play from the wings usually leads to a lot of crosses.

The percentage of goals scored after a set play varies between $23.3-26 \%$. Based on the results it was determined that the most goals scored after a corner or penalty. The free kick (indirect) was ranked third of the most frequent means of scoring in the above UCL tournaments, as we can observe a significant number of goals scored in this way. The coaches dedicate a lot of attention to those cases because every set play near the opponent's penalty box is a chance to score a goal. In this study it was determined that the percentage of goals that came from open play increased in the last two UCL tournaments by almost $2 \%$, and decreased the percentage of goals scored from set play. Similar results were mentioned by Njororai (2013) in a world cup. Some reasons that lead to this decrease are improved defensive strategies, the improper execution of free kicks and corners, the illegal plays of defensive player which referees cannot see, and the absence of creativity of the offensive teams (Roxburgh, 1996).

\section{CONCLUSION}

The greater frequency of goals during the second half depended on a lot of factors, including fatigue, coach strategy and lapses in concentration. Coaches have to pay attention to physical condition and to maintain their players' concentration until the end of the match. Additionally, players have to be trained in combinations, crosses and corners.

\section{REFERENCES}

Abt, G.A., Dickson, G., \& Mummery, W.K. (2002). Goal scoring patterns over the course of a match: An analysis of the Australian National Soccer League. In: W. Spinks, T. Reilly, \& A. Murphy (Eds.), (pp. 107111), Science and Football IV, Routledge London.

Armatas, V., \& Yiannakos, A. (2007). Record and evaluation of set-plays in European Football Championship in Portugal 2004. Inquiries in Sport \& Physical Education, 5(2), 302-307.

Armatas, V., Yiannakos, A., \& Sileloglou, P. (2007). Relationship between time and goal scoring in soccer games: Analysis of three World Cups. International Journal of Performance Analysis in Sport, 7(2), 48-58.

Borrie, A., Jonsson, G., \& Magnusson, M. (2002). Temporal pattern analysis and its applicability in sport: an explanation and exemplar data. Journal of Sports Sciences, 20, 845-852.

Cachay, K., \& Thiel, A. (2000). Soziologie des sports (Sociology of sports). Munchen: Juventa-Verlag. In German

Drust, B., Reilly, T., \& Rienzi, E. (1998). A motion-analysis of work-rate profiles of elite international soccer players, Retrived on Avgust, 7, from the World Wide Web: www.ecss.de/ASP/EDSS/C02/02-0125.pdf

Franks, I.M., \& Miller, G. (1986). Eyewitness testimony in sport. Journal of Sport Behavior, 9, 39-45.

Garganta, J., Maia, J., \& Basto, F. (1997). Analysis of goal scoring patterns in European top-level soccer teams. In T. Reilly, J. Bangsbo, \& M. Hughes (Eds.), Science and Football. (pp. 246-250), Leistungssport.

Hohmann, A., \& Rommel, G. (1994). Spielbeobachtung im Fußball (Game watching in football). Leistungssport, 24(6S), 41-46. In German

Jinshan, X. (1986). The analysis of the techniques, tactics and scoring situations of the 13th World Cup. Sandong Sports Science and Technique, (April), 89-91.

Jinshan, X., Xiakone, C., Yamanaka, K., \& Matsumoto, M. (1993). Analysis of the goals in the 14th World Cup. In: T. Reilly, J. Clarys, \& A. Stibbe, (Eds.), Science and Football II. London. (pp. 203-205), E. and F. Spon. 
Krustrup, P., Mohr, M., Steensberg, A., Bencke, J., Kjær, M., \& Bangsbo, J. (2006). Muscle and blood metabolites during a soccer game: Implications for sprint performance. Medicine \& Science in Sports \& Exercise, 38(6), 1-10.

Lames, M. (1991). Leistungsdiagnostik durch Computersimulation (Performance diagnostics through computer simulation). Frankfurt/Main: Thun. In German

Lames, M. (1994). Systematische Spielbeobachtung (Systematic game observation). Münster: Philippka. In German

Liebermann, D.G., Katz, L., Hughes, M.D., Bartlett, R.M., Mc Clements, J., \& Franks, I.M. (2002). Advances in the application of information technology to sport performance. Journal of Sports Sciences, 20,755-769.

Leite, S.S.W. (2013). Analysis of goals in soccer world cups and the determination of the critical phase of the game. Facta Universitatis Series Physical Education and Sport, 11(3), 247-253.

Lottermann, S. (2000). Tore machen wie Kluivert und Co (Making goals like Kluivert and Co). Fußballtraining, 22(10S), 6-17. In German

Michaildis, Y., Michaildis, C., \& Primpa, E. (2013). Analysis of goals scored in European championship 2012. Journal of Human Sport \& Exercise, 8(2), 367-375.

Michailidis, C., Michailidis, I., Papaiakovou, G., \& Papaiakovou, I. (2004). Analysis and evaluation of way and place that goals were achieved during the European Champions League of Football 2002-2003. Sports Organization, 2(1), 48-54.

Michailidis, Y. (2014). Analysis of goals scored in the 2014 World Cup soccer tournament held in Brazil. International Journal of Sport Studies, 4(9), 1017-1026.

Mohr, M., Krustrup, P., \& Bangsbo, J. (2005). Fatigue in soccer: A brief review. Journal of Sports Sciences, 23, 593-599.

Mohr, M., Krustrup, P., Nybo, L., Nielsen, J.J., \& Bangsbo, J. (2004a). Muscle temperature and sprint performance during soccer matches-beneficial effects of rewarm-up at half time. Scandinavian Journal of Medicine \& Science in Sports, 14, 156-162.

Mohr, M., Nordsborg, N., Nielsen, J.J., Pedersen, L.D., Fischer, C., Krustrup, P., \& Bangsbo, J. (2004b). Potassium kinetics in human interstitium during repeated intense exercise in relation to fatigue. Pflugers Arch, 448, 452-456.

Njororai, W.W.S. (2013). Analysis of goals scored in the 2010 World Cup soccer tournament held in South Africa. Journal of Physical Education \& Sport, 13(1), 6-13.

Olsen, E. (1988). An analysis of goal scoring strategies in the world championship in Mexico 1986. In T. Reilly, A. Lees, K. Davids, \& W.J. Murphy (Eds.). Science and Football. London: E. and F.N. Spon.

Reilly, T. (1996). Motion analysis and physiological demands. In: T. Reilly, J. Bangsbo, \& M. Hughes (Eds.), Science and Football IV. (pp. 65-81), E. \& F. Spon, London.

Ridder, G., Cramer, S., \& Hopstaken, P. (1994). Down to ten: estimating the effect of a red card in soccer. Journal of American Statistic Association, 89, 1124-1127.

Roxburgh, A. (1996). Euro' 96 Technical Report. Nyon: UEFA. Retrived Avgust 15, on the World Wide Web: https://www.uefa.com/multimediafiles/download/publications/uefa/uefamedia/75/74/69/757469_download.pdf

Singer, R., \& Willimczik, K. (2002). Sozialwissenschaftliche forschungsmethoden in der sportwissenschaft: eine einfuihrung (Social science research methods in sports science: an introduction). Sports Organ, Hamburg: Czwalina. In German

Van Gool, D., Van Gerven, D., \& Boutmans, J. (1988). The physiological load imposed on soccer players during real match play. In T. Reilly, A. Lees, K. Davids, \& W.J. Murphy (Eds.), Science and Football. (pp. 51-59), London/New York: E \& F.N. Spon.

Wedegärtner, D. (2004). So einfach ist Flügelspiel nicht (Playing is not that easy). Fußballtraining, 22(10S), 617. In German

Yiannakos, A., \& Armatas, V. (2006). Evaluation of the goal scoring patterns in European Championship in Portugal 2004. International Journal of Performance Analysis in Sport, 6(1), 178-188. 


\section{PROCENA POSTIZANJA GOLOVA I ODNOS IZMEĐU MINUTA IGRE I POSTIZANJE GOLOVA TOKOM ČETIRI TURNIRA UEFA LIGE ŠAMPIONA}

Cilj istraživanja bio je da se poredi vreme i plan igre za postizanje golova tokom četiri turnira UEFA lige šampiona (UCL) (2013-2017). Sve utakmice $(n=500)$ četiri turnira snimljene su $i$ anlizirane Sportsscout softverom. Metoda hi-kvadrata korišćena je za analizu podataka, a nivo značajnosti bio je $p<0.05$. Nije bilo statistički značajnih razlika između vremena i plana igre za postizanje golova između dva UCL takmičenja $\left(X^{2}=84.500, p>0.05\right.$ za vreme, $X^{2}=25.350, p>0.05$ tokom igre $X^{2}=7.503, p>0.05$ za korner ili slobodne šuteve na gol). Petnaestominutnom analizom za svako takmičenje nisu utvrđene statistički značajne razlike, uz izostavljanje produžetaka. Ipak, tokom UCL 2013-2014 i 2015-2016 višse golova postignuto je tokom druge polovine utakmice $\left(X^{2}=9.696\right.$, $p<0.05$ i $X^{2}=7.496, p<0.05$, tim redosledom). Više golova postignuto je iz igre nego tokom kornera ili slobodnih šuteva na gol (75\% i $25 \%$ u proseku, tim redosledom). Akcije koje su rezultovale najvećim brojem postignutih golova tokom igre sastojale su se od kombinacija i dodavanja $(21.6 \%$ i $22.4 \%$ tim redosledom) a tokom kornera ili penala (33.9\%, u oba slučaja). Rezultati su pokazali da nema statistički značajnih razlika između CL u pogledu planova igre za postizanje golova $i$ vremena potrebnog za postizanje golova. Ipak, postizanje golova moglo bi biti zavisna varijabla jer je više golova postignuto u drugoj polovini utakmice. Objašnjenje za ovo bi mogao da bude umor i taktika igre. Što se plana igre tiče, treneri bi trebalo da se fokusiraju na vežbe dodavanja lopte i kombinacije dodavanja. Takođe, više pažnje bi trebalo posvetiti izvođenju kornera.

Ključne reči: fudbal, liga šampiona, gol, video analiza 